\title{
New targeted therapies in myelodysplastic syndrome: the role of farnesyltransferase and proteasome inhibitors
}

\author{
A Cristina Gonçalves ${ }^{1,3 *}$, Ana Oliveira ${ }^{2}$, Diana Moreira² ${ }^{2}$ Silvia Neves ${ }^{3,4}$, Vera Alves ${ }^{1}$, Teresa Silva ${ }^{1}$, Luís Mesquita ${ }^{1}$, \\ Henriqueta Coimbra ${ }^{1,3}$, Marília Dourado ${ }^{1,3}$, José M Nascimento-Costa ${ }^{1,3,4,5}$, Ana B SarmentoRibeiro $1,3,6$
}

From 16th International Charles Heidelberger Symposium on Cancer Research

Coimbra, Portugal. 26-28 September 2010

One of the main mechanisms responsible for MDS molecular pathogenesis involves the activation of tyrosine-kinase receptors, such as FLT3, RAS proteins, and deregulation of apoptotic pathways. Regarding this, new drugs have been developed to target pathways involved in malignancy, such as Farnesyltransferase Inhibitors (IFTs) and proteasome inhibitors (PI). This work aims to clarify the role of IFTs and PI as potential therapeutic agents in Myelodysplastic Syndrome (MDS).

For this, F-36P cells, were incubated with different concentrations of $\alpha$-HFPA (IFT) and MG262 (PI), as single agents and in association with the conventional therapeutic drug, Cytosine Arabinoside (Ara-C). Cell growth and viability was evaluated by Trypan Blue test. Cell death was analyzed by optic microscopy and flow cytometry (FC). Expression of proteins involved in apoptosis and cell cycle regulation was evaluated by FC. The detection of RAS and FLT3 mutations was accessed by sequentiation and PCR, respectively.

Our results show that $\alpha-\mathrm{HFPA}$ and MG262, in monotherapy, induce a decrease in cell growth and viability in a time and dose-dependent manner $\left(\mathrm{IC}_{50}, \alpha\right.$-HFPA 125 $\mu \mathrm{M}$; MG262 $100 \mathrm{nM}$ ). The antiproliferative effect of $\alpha$-HFPA could be related to RAS/MAPK pathway inhibition, as we observed a decrease in cyclin D1 levels, while the cytotoxicity induced by MG262 to an increase in BAX expression. Our results show that $\alpha$-HFPA is effective independently of $R A S$ mutations, once we didn't identify mutations in none of the isoforms studied, but we observe ITD mutations in FLT3 gene.

\footnotetext{
* Correspondence: acgoncalves@fmed.uc.pt

${ }^{1}$ Faculty of Medicine, University of Coimbra (FMUC), Coimbra, Portugal
}

Full list of author information is available at the end of the article
These results suggest that IFTs and PIs may constitute a potential therapeutic approach as single agents in MDS.

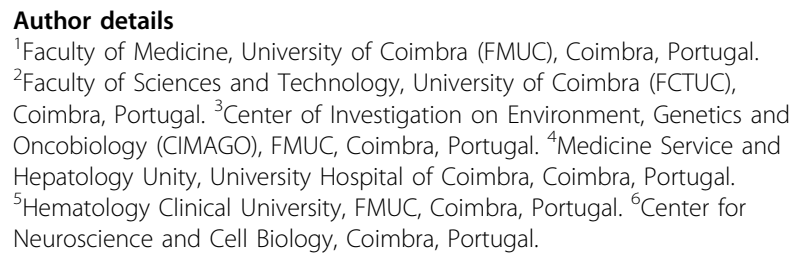

Published: 24 September 2010

doi:
Cite this article as: Gonçalves et al:: New targeted therapies in
myelodysplastic syndrome: the role of farnesyltransferase and proteasome inhibitors. BMC Proceedings 2010 4(Suppl 2):P44.
Submit your next manuscript to BioMed Central and take full advantage of:

- Convenient online submission

- Thorough peer review

- No space constraints or color figure charges

- Immediate publication on acceptance

- Inclusion in PubMed, CAS, Scopus and Google Scholar

- Research which is freely available for redistribution

Submit your manuscript at www.biomedcentral.com/submit
Biomed Central 